\title{
Possible predictive markers related to micro-metastasis in breast cancer patients
}

\author{
LI ZHU ${ }^{1,2}$, WINGS T.Y. LOO ${ }^{1}$, CARTER W.N. CHENG ${ }^{1}$ and LOUIS W.C.CHOW ${ }^{1}$
}

\author{
${ }^{1}$ Hung Chao Hong Integrated Centre For Breast Diseases, Department of Surgery, The University of Hong Kong, Hong Kong; \\ ${ }^{2}$ Department of Surgery, Ruijin Hospital, Faculty of Medicine, Shanghai Jiao Tong University, Shanghai 200025, P.R. China
}

Received November 1, 2005; Accepted December 20, 2005

\begin{abstract}
Despite significant advances in micro-metastasis detection methods, little is known about the relationship between micro-metastasis and primary tumors. The purpose of this study was to assess the ability of expression of the breast cancer-related markers, HER-2/neu, COX-2, VEGF and PDGF-B, as a predictor for micro-metastasis. As destination sites for micro-metastasis, we examined the peripheral blood (BD), bone marrow (BM) and sentinel lymph node (SLN) from 53 breast cancer patients. Protein and gene expression of the markers at the primary site were determined by immunohistochemistry (IHC) and quantitative RT-PCR. BD and BM samples were processed using magnetic-activated cell separation and immunocytochemistry. SLNs were examined by hematoxylin and eosin (H\&E) staining and IHC. The percentages of patients with micro-metastasis were $24.5 \%$ in BD, $56.6 \%$ in BM, $26.4 \%$ in SLN by H\&E and $41.5 \%$ in SLN by IHC. COX-2 gene amplification was significantly associated with SLN micro-metastasis by $\mathrm{H} \& \mathrm{E}(\mathrm{P}=0.03)$. Overexpression of HER-2/neu predicts the presence of SLN micro-metastasis as detected by $\mathrm{H} \& \mathrm{E}(\mathrm{P}=0.005)$ and $\mathrm{COX}-2$ overexpression predicts the presence of micro-metastasis in $\mathrm{BM}(\mathrm{P}=0.005)$ and SLN by H\&E $(\mathrm{P}<0.001)$ and IHC $(\mathrm{P}<0.001)$. Similarly, PDGF-B overexpression predicts micro-metastasis in BD $(\mathrm{P}=0.002), \mathrm{BM}(\mathrm{P}=0.003)$ and SLN by $\mathrm{H} \& \mathrm{E}(\mathrm{P}=0.017)$, whereas VEGF overexpression predicts only the presence of SLN micro-metastasis by IHC $(\mathrm{P}=0.001)$. Our results indicate the possible value of using these markers to predict the risk of micro-metastasis in breast cancer.
\end{abstract}

\section{Introduction}

Relapse is a recognized consequence of early tumor cell dissemination in breast cancer patients (1-4). The detection

Correspondence to: Dr Louis W.C. Chow, Department of Surgery, Queen Mary Hospital, University of Hong Kong Medical Centre, Pokfulam Road, Hong Kong, P.R. China

E-mail: 1wcchow@hkucc.hku.hk)

Key words: blood, bone marrow, sentinel lymph node, magneticactivated cell separation, quantitative RT-PCR of micro-metastasis has thus become an issue of significant interest. In the last decade, many new immunological and molecular procedures have been developed to detect micrometastasis throughout the body $(5,6)$. Much work has also been conducted to determine the genetic and phenotypic characteristics of these cells. Markers are still needed which can indicate the presence or absence of micro-metastasis. Four molecules, two metastasis-associated factors in breast cancer (HER-2/neu and COX-2) and two angiogenesis-associated factors (VEGF and PDGF-B) were examined to determine their relationships (if any) to micro-metastatic spread.

HER-2/neu and COX-2 are widely investigated molecules related to metastasis in breast cancer. Human epidermal growth factor receptor-2 (HER-2) is a cell-surface glycoprotein designated the HER-2 or c-erbB-2 receptor that belongs to the tyrosine kinase receptor family. HER-2/neu is amplified and/or its protein is overexpressed in $15-25 \%$ of breast cancers (7-10). It has been associated with poor clinical outcome and, possibly, tamoxifen resistance (11-15). Cyclooxygenase-2 $(\mathrm{COX}-2)$ is an enzyme responsible for the conversion of arachidonic acid to prostaglandin $\mathrm{E}_{2}\left(\mathrm{PGE}_{2}\right)$ in three steps (16-19). Overexpression is found in 17-68\% of invasive breast cancers and similarly predicts poorer survival rates $(20,21)$.

Both PDGF/VEGF belong to the vascular endothelial growth factor family and have been associated with a worse prognosis and metastatic spread (22-24). Vascular endothelial growth factor (VEGF) is a heparin-binding homodimeric glycoprotein which plays crucial stimulatory roles in tumor angiogenesis. Its release is often triggered by the unusual hypoxic conditions found within tumors (25). The family of Plateletderived growth factor (PDGF) consists of four gene products that form five dimeric isoforms. In particular, PDGF-B is thought to stimulate tumor growth through tumor stromal cells expressing the PDGF 3 -receptor in a paracrine fashion through its homodimeric isoform, PDGF-BB (26). There is some speculation that it may play a critical role in metastatic spread by helping disseminating cells adjust to the microenvironments of distant sites (27).

Quantitative reverse transcription PCR (QRT-PCR) is a relatively new modality used to precisely quantify gene expression levels within cells (28). The use of fluorescence probes allows for precise quantification of the amount of PCR product which is then compared to the quantification levels of a housekeeping gene such as $\beta$-actin (29). In order to determine the expression profile at both mRNA level and 
protein level, we combined this with immunohistochemistry (IHC) to assess association of expression of these markers in primary breast cancer tumors with micro-metastasis in the blood (BD), bone marrow (BM) and sentinel lymph nodes (SLNs). The primary end-point was to determine whether the expression of these factors could be used to predict micrometastatic spread in the above three sites.

\section{Patients and methods}

Patients. From April 2003 to March 2004, 53 patients with histology-confirmed breast cancer consented to enter this study at the Department of Surgery, University of Hong Kong Medical Centre. Preoperative examination of the patients showed no evidence of distant metastasis at the time of primary surgery. Blood and bone marrow (BM) samples were collected simultaneously immediately prior to surgery. Primary breast tumors and sentinel lymph nodes (SLNs) were collected during surgery. After surgical dissection, the tumor samples were macroscopically isolated from the specimens. Samples were divided into three parts: one was subjected to routine pathological examination, one was frozen immediately in liquid nitrogen for RNA extraction and one was fixed in formalin and later embedded in paraffin wax. The SLN was divided into two parts: one was subjected to pathological examination and the other was fixed in formalin and later embedded in paraffin wax.

Magnetic-activated cell separation (MACS). Two bilateral bone marrow samples were obtained under general anesthesia from both upper iliac crests of each patient through fine needle aspiration during primary surgery and collected in EDTA anticoagulant. At the same time, blood samples from a peripheral vein were also collected. The blood and bone marrow samples were both subjected to magnetic-activated cell separation (MACS) as previously described (30). In brief, red blood cells were removed and the cell pellet was fixed with a 1/9 mixture of MACS CellFix solution and MACS dilution buffer. The procedures for carcinoma cell enrichment and detection were performed according to the manufacturer's instructions (Miltenyi Biotec, Germany). The fixed nucleated cells were permeabilized with MACS CellPerm solution and the cell pellet was incubated with MACS CK microbeads. After removal of unbound antibodies, the pellet was suspended in staining buffer. The suspension was put through a Nylon mesh to remove cell clumps and then a MACS enrichment column, which was located in a magnet. The enriched cells were eluted using a plunger.

Immunocytochemistry (ICC). Approximately $2-10 \times 10^{7}$ nucleated cells were enriched and immunostained. The sample slides were made by cytospinning up to $5 \times 10^{5}$ cells. After incubating with $3 \% \mathrm{H}_{2} \mathrm{O}_{2}$ and washing in PBS, the slides were incubated with $1 / 100$ anti-CK-FITC at $4^{\circ} \mathrm{C}$ overnight. Sections were incubated with $1 / 300$ biotinylated rabbit antibody against mice. Color development was performed with AEC and then counterstained with hematoxylin. Cells were scored as immunocytochemically positive only when showing moderate to strong staining intensity. Positive cells were considered to be breast cancer cells only if they had tumor morphology and lacked hematopoietic characteristics.
Quantitative reverse transcription PCR ( $Q R T-P C R)$. RNA was extracted from liquid-nitrogen-frozen tissue samples using an SV Total RNA isolation system (Promega, Madison, WI, USA) as specified by the manufacturer's instructions. The quantity and quality of the extracted RNA was confirmed by absorption measurements at 260 and $280 \mathrm{~nm}$ using a spectrophotometer (U-1800, HITACHI, Tokyo, Japan). The reagents for firststrand cDNA synthesis were included in the SuperScript III first-strand synthesis system from Invitrogen Inc. (Carlsbad, CA, USA). The final volume of reverse transcription (RT) reaction mixture was $20 \mu \mathrm{l}$, which contained $1 \mu \mathrm{g}$ of total RNA, $0.5 \mu \mathrm{g}$ Oligo(dT) $)_{20}, 2 \mu 1$ 10X PCR buffer, $5 \times 10^{-5} \mathrm{mmol}$ $\mathrm{MgCl}_{2}, 2 \times 10^{-4} \mathrm{mmol}$ DTT, $1 \mu 110 \mathrm{mM}$ dNTP mix and 2000 units of SuperScript III RT. The cDNA was synthesized as recommended by the manufacturer. Two units of RNase $\mathrm{H}$ were added to the mixture and then the mixture was incubated at $37^{\circ} \mathrm{C}$ for $20 \mathrm{~min}$.

A QRT-PCR assay was developed to detect the expression of the mRNA of HER-2/neu, COX-2, VEGF and PDGF-B. The expression of the target genes was measured by real-time PCR using the ABI 7700 PRISM sequence detector (PE Applied Biosystems, Foster City, CA, USA). Specific primers and 6-carboxyfluorescein (FAM)-labeled TaqMan ${ }^{\circledR}$ probes were used in combination. Primers were designed to span intron-exon junctions to exclude genomic DNA from amplification. PCR cycles were performed using TaqMan Universal PCR Master Mix (PE Applied Biosystems) that contained Ampli-Taq Gold DNA polymerase, a reaction buffer, dNTP, dUTP and AmpErase uracil-N-glycosylase and Assayson-Demand gene expression probes (PE Applied Biosystems). PCR was carried out for 1 cycle at $50^{\circ} \mathrm{C}$ for $2 \mathrm{~min}, 1$ cycle at $95^{\circ} \mathrm{C}$ for $10 \mathrm{~min}$, and 40 cycles at $95^{\circ} \mathrm{C}$ for $15 \mathrm{sec}$ followed by $60^{\circ} \mathrm{C}$ for $1 \mathrm{~min}$ and $68^{\circ} \mathrm{C}$ for $1 \mathrm{~min}$. PCR amplification of actin mRNA was conducted according to the manufacturer's instructions for the TaqMan actin control reagent.

The amounts of target mRNA in the samples were quantified relative to the control cDNA and standardized with respect to $B$-actin mRNA. The quantification value of target gene mRNA was described as an amount relative to the control cDNA. As a negative control, 24 normal breast tissue samples were obtained at the time of surgery and studied in order to determine the cut-off value of QRT-PCR assay.

Immunohistochemistry (IHC). Consecutive 4- $\mu \mathrm{m}$ tissue sections were cut from the paraffin blocks of both SLN and primary tumors and placed on charged poly-L-lysine-coated slides (Menzel-Glaser, Germany). After dewaxing, one set of the SLN slide was stained with hematoxylin and eosin (H\&E). A second set was stained with anti-pancytokeratin (Pan-CK) as an immunohistochemical marker to determine whether this improved the sensitivity of the test. Immunohistochemistry was performed using a standard technique of buffer wash and incubation with primary and secondary antibodies using a streptavidin-biotin complex (Dako Corp., CA, USA) and immunoperoxidase with the labeling antigen, diaminobenzidine. Cells were then counterstained with hematoxylin to highlight the nuclei before undergoing fixation and mounting. The number of isolated lymph nodes, the number of metastatic lymph nodes and the size of the metastasis $(\leq 2$ or $>2 \mathrm{~mm}$ ) were recorded. 
Table I. Primary antibodies.

\begin{tabular}{|c|c|c|c|c|}
\hline Antibody & Nature of determinant & Reagent provided & Source & Dilution \\
\hline $\begin{array}{l}\mathrm{C} \text {-erb-B2 onco- } \\
\text { protein }\end{array}$ & $\begin{array}{l}\text { Epidermal growth } \\
\text { factor receptor } 2\end{array}$ & $\begin{array}{l}\text { Polyclonal, rabbit } \\
\text { anti-human }\end{array}$ & $\begin{array}{l}\text { Dako, Inc., Carpinteria, } \\
\text { CA, USA }\end{array}$ & $1: 250$ \\
\hline COX-2 (229) & $\begin{array}{l}\text { Membrane-bound } \\
\text { enzyme }\end{array}$ & $\begin{array}{l}\text { Monoclonal, mouse } \\
\text { anti-human }\end{array}$ & $\begin{array}{l}\text { Zymed Laboratories, Inc., South } \\
\text { San Francisco, CA, USA }\end{array}$ & $1: 100$ \\
\hline VEGF (147) & $\begin{array}{l}\text { Vascular endothelial } \\
\text { growth factor }\end{array}$ & $\begin{array}{l}\text { Polyclonal, rabbit } \\
\text { anti-human }\end{array}$ & $\begin{array}{l}\text { Santa Cruz Biotechnology, } \\
\text { Inc., CA, USA }\end{array}$ & $1: 100$ \\
\hline $\begin{array}{l}\text { PDGF-B } \\
(\mathrm{Ab}-1)\end{array}$ & $\begin{array}{l}\text { Platelet-derived growth } \\
\text { factor-B chain }\end{array}$ & $\begin{array}{l}\text { Polyclonal, rabbit } \\
\text { anti-human }\end{array}$ & $\begin{array}{l}\text { Oncogene, San Diego, } \\
\text { CA, USA }\end{array}$ & $1: 100$ \\
\hline
\end{tabular}

For tumor sample slides, antigen retrieval was performed through boiling the tissue sections at $95^{\circ} \mathrm{C}$ in $10 \mathrm{mmol} / \mathrm{l}$ citrate buffer for $10 \mathrm{~min}$. The sections were cooled and treated with peroxidase-blocking reagent for $20 \mathrm{~min}$, rinsed and treated with sufficient primary antibodies (HER-2/neu, COX-2, VEGF and PDGF-B) to cover the entire tissue section for $30 \mathrm{~min}$. The details for the primary antibodies are given in Table I. Sections were rinsed again and treated for $30 \mathrm{~min}$ with visualization reagent solution containing both secondary goat anti-rabbit antibody and horseradish peroxidase linked to a common dextran polymer backbone. After rinsing away the excess visualization reagent, the sections were incubated in diaminobenzidine for $10 \mathrm{~min}$ to identify the location of immunoprecipitates. Sections were then counterstained with hematoxylin and eosin, and then mounted in Permount. Immunostaining was interpreted using a bright-field Olympus microscope according to the scoring system of the manufacturer as $0,1+, 2+$ and $3+$. Scores of $2+$ and $3+$ were considered as overexpression and scores of 0 and $1+$ were considered as low expression. Controls without primary antibody and positive control tissue were included in all experiments to ensure the staining quality.

Statistical analysis. Univariate statistical summaries (means and range of $95 \%$ confidence intervals for continuous variables and proportions for categorical variables) were used to describe the demographic and clinical characteristics of the samples. For categorical variables, the $\chi^{2}$ test was used. The gene expression profiles (expression fold above normal) between groups of patients with/without micro-metastasis were analyzed using an independent sample t-test. $\mathrm{P}<0.05$ was considered statistically significant and all the P-values were two-sided.

\section{Results}

Determination of micro-metastasis in different homing sites. Micro-metastasis of the blood and bone marrow were detected in $13(24.5 \%)$ and $30(56.6 \%)$ of 53 patients respectively by ICC following MACS. In 14 (26.4\%) patients, SLN micrometastasis was detected by $\mathrm{H} \& \mathrm{E}$ staining. By contrast, 22 $(41.5 \%)$ had micro-metastasis detected by IHC. In 44 (84\%) cases, the results of the two assay methods were the same. In

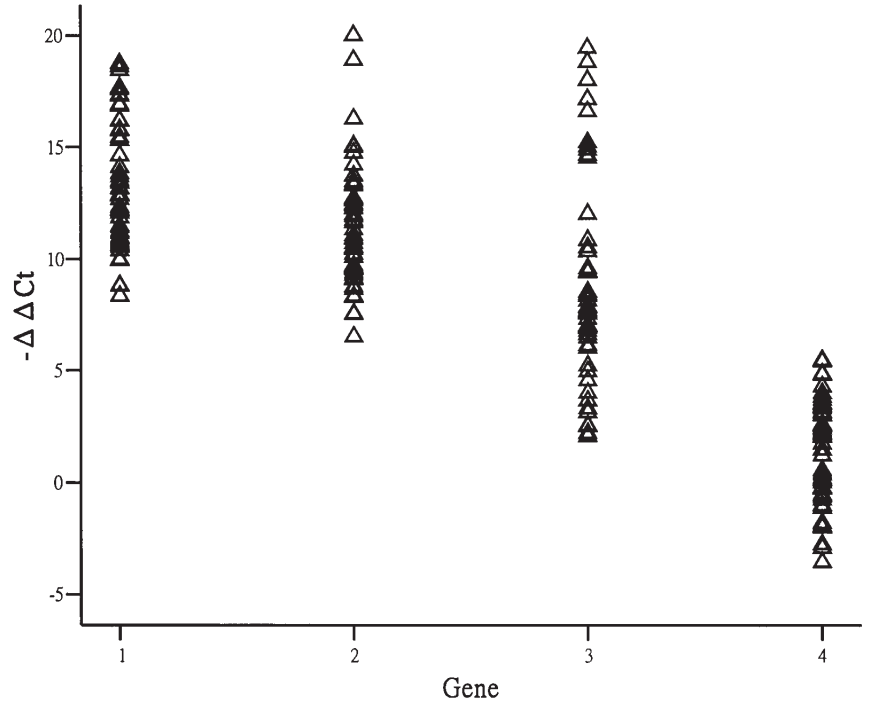

Figure 1. Relative gene expression levels in primary tumors. Real-time RT-PCR analysis of relative gene expression levels of different markers in primary breast cancer. (Gene 1: PDGF-B; 2: COX-2; 3: HER-2/neu; 4: VEGF).

$14(22 \%)$ cases, they were positive by both methods and, in $39(62 \%)$, they were negative by both methods.

Gene expression of different markers. For each gene, $\Delta \mathrm{Ct}$ values for normal control and breast tumor tissues were obtained from triplicate reactions. We observed that, in the normal control tissue, HER-2/neu, COX-2, VEGF and PDGF-B had the highest $\Delta \mathrm{Ct}$ values, reflecting the fact that these genes were expressed at the lowest levels in normal tissue. Relative gene expression levels in individual primary tumor samples can be readily derived from real-time RT-PCR data using the equation $2^{-\Delta \Delta C t}(31)$, and $\Delta \Delta C t$ is the difference between the mean $\Delta \mathrm{Ct}$ value in normal control samples and the $\Delta \mathrm{Ct}$ value in the experimental primary tumor sample. The values (of $-\Delta \Delta \mathrm{Ct}$ ) for breast cancer-associated genes are shown for the primary tumor samples (Fig. 1). The levels of COX-2 overexpression varied the most and ranged from 1- to $4.9 \times 10^{5}$-fold above normal. The levels of HER-2/neu and 
Table II. Gene expression fold above normal in primary tumors related to presence and absence of BD and BM micrometastasis.

\begin{tabular}{|c|c|c|c|c|c|c|}
\hline \multirow[b]{2}{*}{ Genes } & \multicolumn{3}{|c|}{ BD micro-metastasis } & \multicolumn{3}{|c|}{ BM micro-metastasis } \\
\hline & Mean & $\begin{array}{c}95 \% \text { CI } \\
\text { (Lower; Upper) }\end{array}$ & $\begin{array}{l}\text { Sig. (2-tailed) } \\
\text { P-value }\end{array}$ & Mean & $\begin{array}{c}\text { 95\% CI } \\
\text { (Lower; Upper) }\end{array}$ & $\begin{array}{c}\text { Sig. (2-tailed) } \\
\text { P-value }\end{array}$ \\
\hline \multicolumn{7}{|c|}{ HER-2/neu } \\
\hline$(-)$ & $26,923.27$ & $(-108,282.52 ; 45,943.94)$ & 0.42 & $6,701.49$ & $(-107,975.75 ; 9,512.08)$ & 0.09 \\
\hline$(+)$ & $58,092.56$ & & & $55,933.32$ & & \\
\hline \multicolumn{7}{|c|}{ COX-2 } \\
\hline$(-)$ & $19,423.79$ & $(-243,925.07 ; 107,520.84)$ & 0.42 & $6,294.76$ & $(-130,136.76 ; 24,639.01)$ & 0.17 \\
\hline$(+)$ & $87,625.90$ & & & $59,043.63$ & & \\
\hline \multicolumn{7}{|l|}{ VEGF } \\
\hline$(-)$ & 7.09 & $(-5.75 ; 6.76)$ & 0.87 & 4.68 & $(-9.34 ; 1.28)$ & 0.11 \\
\hline$(+)$ & 6.58 & & & 8.71 & & \\
\hline \multicolumn{7}{|c|}{ PDGF-B } \\
\hline$(-)$ & $45,254.95$ & $(-93,752.36 ; 36,459.84)$ & 0.38 & $24,362.11$ & $(-99,637.17 ; 989.04)$ & 0.05 \\
\hline$(+)$ & $73,901.21$ & & & $73,686.18$ & & \\
\hline
\end{tabular}

Table III. Gene expression fold above normal in primary tumors related to presence and absence of SLN micro-metastasis (detected by H\&E and IHC).

\begin{tabular}{|c|c|c|c|c|c|c|}
\hline \multirow[b]{2}{*}{ Genes } & \multicolumn{3}{|c|}{$\mathrm{H} \& \mathrm{E}$} & \multicolumn{3}{|c|}{ IHC } \\
\hline & Mean & $\begin{array}{c}95 \% \text { CI } \\
\text { (Lower; Upper) }\end{array}$ & $\begin{array}{l}\text { Sig. (2-tailed) } \\
\text { P-value }\end{array}$ & Mean & $\begin{array}{c}95 \% \text { CI } \\
\text { (Lower; Upper) }\end{array}$ & $\begin{array}{l}\text { Sig. (2-tailed) } \\
\text { P-value }\end{array}$ \\
\hline \multicolumn{7}{|c|}{ HER-2/neu } \\
\hline$(-)$ & $15,865.26$ & $(-143,882.11 ; 2,271.38)$ & 0.05 & $17,561.40$ & $(-116,197.26 ; 34,253.67)$ & 0.27 \\
\hline$(+)$ & $86,670.62$ & & & $58,533.20$ & & \\
\hline \multicolumn{7}{|c|}{$\mathrm{COX}-2$} \\
\hline$(-)$ & $8,453.74$ & $(-199,512.08 ;-10,207.89)$ & 0.03 & $9,850.07$ & $(-170,424.36 ; 43,693.94)$ & 0.23 \\
\hline$(+)$ & $113,313.74$ & & & $73,215.28$ & & \\
\hline \multicolumn{7}{|l|}{ VEGF } \\
\hline$(-)$ & 6.85 & $(-6.54 ; 5.67)$ & 0.88 & 6.85 & $(-5.74 ; 5.19)$ & 0.92 \\
\hline$(+)$ & 7.28 & & & 7.12 & & \\
\hline \multicolumn{7}{|c|}{ PDGF-B } \\
\hline$(-)$ & $56,668.88$ & $(-47,240.97 ; 80,460.50)$ & 0.60 & $50,363.19$ & $(-61,889.71 ; 52,647.47)$ & 0.87 \\
\hline$(+)$ & $40,059.11$ & & & $54,984.31$ & & \\
\hline
\end{tabular}

PDGFB overexpression varied from 4- to $4.5 \times 10^{5}$-fold and 328 - to $4.4 \times 10^{5}$-fold above normal. The level of VEGF overexpression was much lower than the above three genes, varying from 0.08 - to 382-fold above normal.

To determine whether the results of the QRT-PCR assay correlated with micro-metastasis, we performed subgroup analysis of individual markers. Tables II and III show the descriptive gene expression fold above normal in primary tumors related to presence and absence of micro-metastasis in different homing sites (BD, BM, SLN detected by H\&E and SLN detected by IHC). Above normal gene expression in primary tumors was much higher in patients with micrometastasis. This strongly suggests that the distribution of QRTPCR results is not random but is associated with the presence of micro-metastasis. When conducting subgroup analysis of individual genes, we found a statistically significant difference 


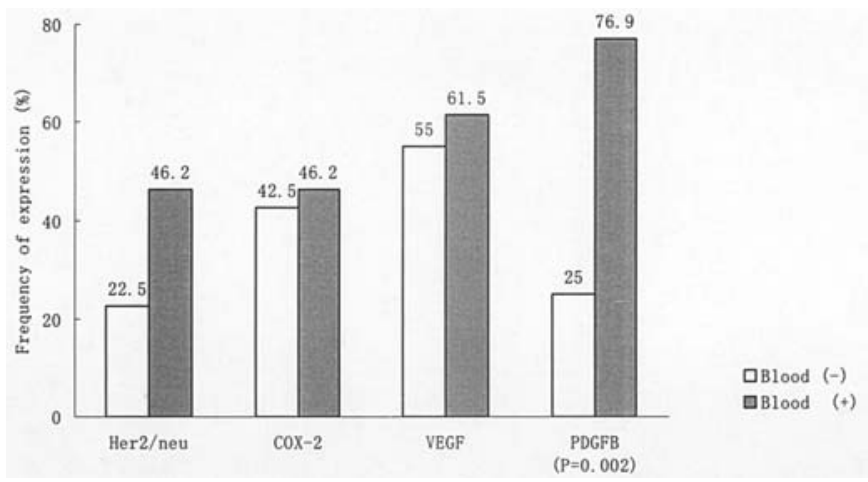

Figure 2. Frequency of protein expression in breast cancer patients with blood micro-metastasis [blood $(+)]$ or not $[$ blood $(-)]$.

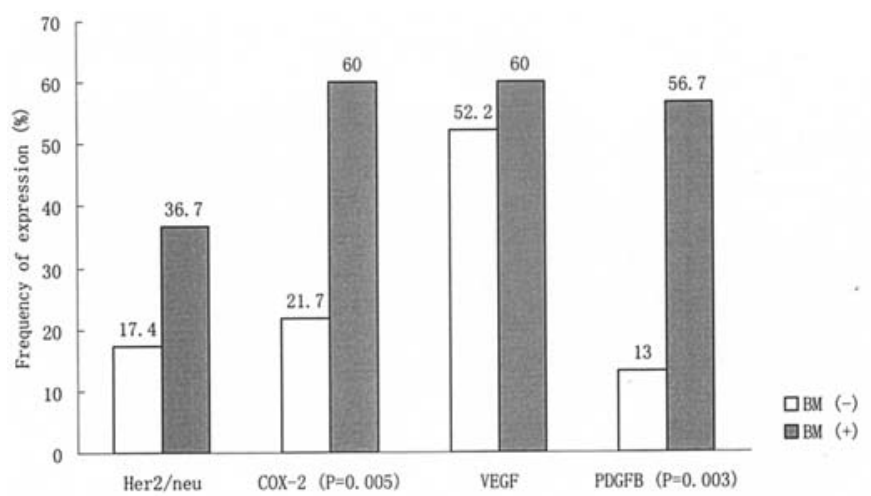

Figure 3. Frequency of protein expression in breast cancer patients with BM micro-metastasis $[\mathrm{BM}(+)]$ or not $[\mathrm{BM}(-)]$.

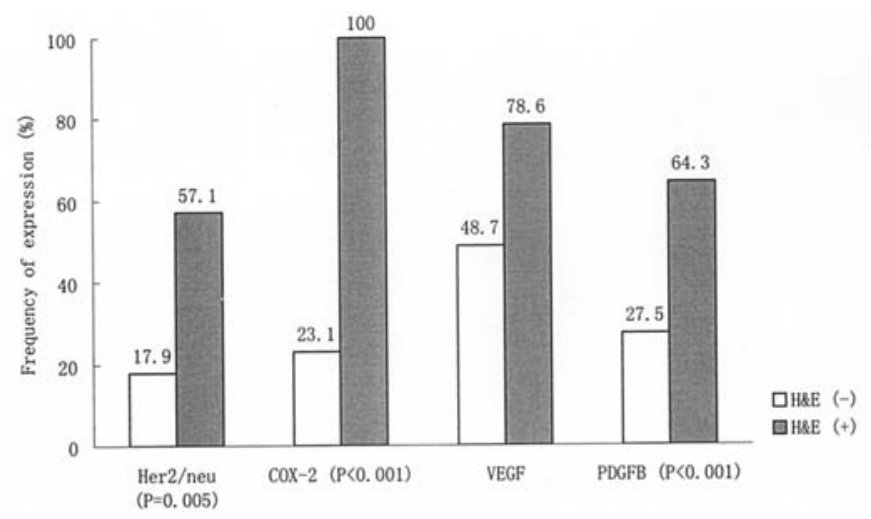

Figure 4. Frequency of protein expression in breast cancer patients with SLN micro-metastasis $[H \& E(+)]$ or not $[H \& E(-)]$ by H\&E.

in $\mathrm{COX}-2$ expression between the presence and absence of SLN micro-metastasis by $\mathrm{H} \& \mathrm{E}(\mathrm{P}=0.03,95 \% \mathrm{CI}=-199,512.09$ to $-10,207.89)$. Also, HER-2/neu and PDGF-B expression levels correlated highly with micro-metastasis in SLN and $\mathrm{BM}$ separately $(\mathrm{P}=0.05)$.

Protein expression of different markers. All markers included in this study were mainly identified in the cytoplasm of breast cancer cells. The expression of different markers in primary breast cancer was $26.4 \%$ for HER-2/neu, $43.4 \%$ for COX-2,

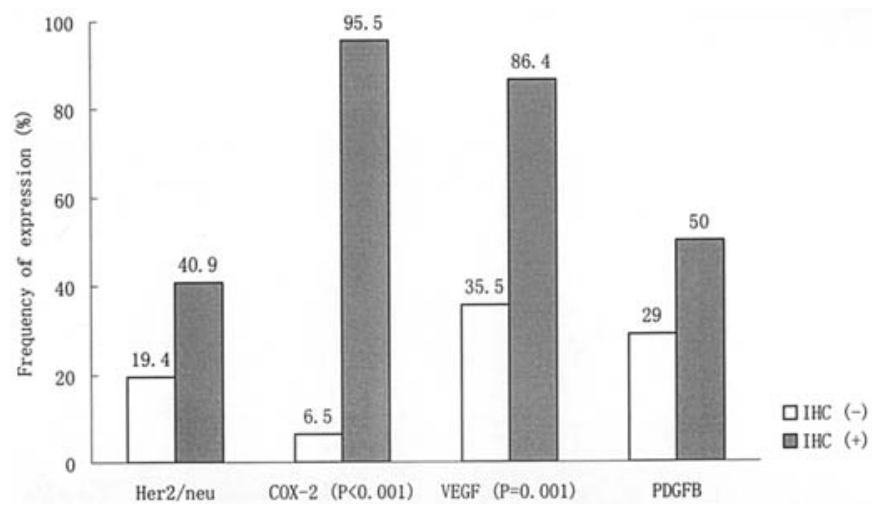

Figure 5. Frequency of protein expression in breast cancer patients with SLN micro-metastasis [IHC (+)] or not [IHC (-)] by IHC.

56.6\% for VEGF and $37.7 \%$ for PDGF-B respectively. To determine the value of multimarker analysis, we evaluated the frequency of protein overexpression in patients with and without micro-metastasis in different homing sites (Figs. 2-5). Overexpression of HER-2/neu predicts the presence of SLN micro-metastasis as detected by $\mathrm{H} \& \mathrm{E}(\mathrm{P}=0.005)$ and $\mathrm{COX}-2$ overexpression predicts the presence of $\mathrm{BM}(\mathrm{P}=0.005)$, SLN by $\mathrm{H} \& \mathrm{E}(\mathrm{P}<0.001)$ and IHC $(\mathrm{P}<0.001)$. Similarly, PDGF-B overexpression predicts $\mathrm{BD}(\mathrm{P}=0.002), \mathrm{BM}(\mathrm{P}=0.003)$ and SLN by $\mathrm{H} \& \mathrm{E}(\mathrm{P}=0.017)$, whereas VEGF overexpression predicts only the presence of SLN by IHC $(\mathrm{P}=0.001)$.

\section{Discussion}

Micro-metastasis is considered to be the missing link between a primary tumor and formation of metastasis. Micro-metastasis of cancer cells in local and distant organs, such as peripheral blood, BM and SLN, generally results in recurrence even after a curative operation (32). For breast cancer, in particular, the detection of micro-metastatis in BM has been suggested as a potential prognostic factor for survival (33-36). Improvements in the sensitivity and specificity of detection methods may yield more important information in the future.

ICC on cytokeratin fragments is one of the best approaches for micro-metastasis detection in BD and BM (37-39). Braun et al (35) in an analysis of the BM of 200 and 500 patients without cancer and with breast cancer respectively detected cytokeratin positive cells in only $1 \%$ of control patients but in $30-40 \%$ of breast cancer patients. Immunomagnetic procedures such as MACS should enhance the sensitivity and consistency of this procedure. We detected rates of 24.5 and $56.6 \%$ respectively for $\mathrm{BD}$ and $\mathrm{BM}$, which is consistent with the 20$52 \%$ and $16-80 \%$ respectively quoted in most studies (40-47).

For detection in SLN, H\&E or immunochemical staining is typically used. IHC for SLN generally tends to yield more positive results than $\mathrm{H} \& \mathrm{E}$; micro-metastasis detected by IHC is approximately $10-20 \%$ in specimens that are negative according to H\&E (48-52). We used both approaches and detected rates of 26.4 and $41.5 \%$ with $\mathrm{H} \& \mathrm{E}$ and IHC respectively. This is consistent with the rates previously detected of $14-32 \%$ by $H \& E$ and $22-45 \%$ by IHC (48-52). Previous research has provided a basis for selecting the factors for study. However, research in general relating biochemical factors to 
metastasis is still quite limited. We know PDGF-B is a potent osteotropic factor that stimulates the functions of both osteoclasts and osteoblasts (53). Yi et al (54) have established an animal model that suggests that MCF-7/neu-derived human PDGF-B plays a causative role in the development of osteosclerotic bone metastasis in breast cancer. In vivo studies have also reported that elevated levels of PDGF in the circulation and increased expression of PDGF in tumors correlate with increased metastases, lower response to chemotherapy, and shorter survival for patients with breast cancer (55-57). Our research found PDGF-B to predict micrometastasis not only in BM but in BD and SLN (by H\&E) as well.

HER-2/neu overexpression on occult metastatic cells in $\mathrm{BM}$ predict a poor clinical outcome for breast cancer patients (58). Furthermore, Braun et al (58) found that HER-2/neu might be important for the growth and survival of disseminated tumor cells. According to our research, HER-2/neu was only related to SLN (by H\&E).

VEGF is known to have a broad stimulatory role in neoangiogenesis and is a potent regulator of breast carcinogenesis (59). Numerous studies have confirmed this in a clinical setting (60-64). VEGF-C and -D overexpression have been also detected in lymph node-positive breast tumors (65). This may be related to its overexpression being predictive of a higher micro-metastatic rate in SLN (by IHC).

Increased concentrations of PGE2, a major product of COX-2, have been reported in human breast cancer and in experimental murine mammary tumor models (66). COX-2 expression has also been proved to associate with angiogenesis and lymph node metastasis in breast cancer patients (21). Our research finds COX-2 is associated with both BM and SLN (by H\&E) micro-metastasis and QRT-PCR detects differences in amplification levels between non-SLN by H\&E positive and negative groups. This finding could indicate that COX-2 expression in human breast cancer might be an early event in tumor progression, in accordance to colorectal and gastric cancer, in which COX-2 plays a role in tumorigenesis and is considered to be an early event (16).

To the best of our knowledge, this is the first study to suggest an association between primary tumors and micrometastasis in different homing sites from breast cancer patients. The current study provides clinical evidence that the overexpression of HER-2/neu, COX-2 and VEGF is associated with the presence of micro-metastasis in SLN while that of PDGF-B is related to micro-metastasis in blood and bone marrow, suggesting that this may be of value for the diagnosis of micro-metastasis in different homing sites.

Our preliminary findings suggest that COX-2 as detected by QRT-PCR is associated with SLN as detected by H\&E and that protein overexpression as detected by IHC can predict micro-metastatic spread. Further work may lead to additional insight-improving prediction of early tumor cell dissemination and help to stratify breast cancer patients at high-risk of metastasis for different treatment as well as identify those at low-risk for whom no further systemic therapy is warranted.

\section{References}

1. Pantel K, Cote RJ and Fodstad $\varnothing$ : Detection and clinical importance of micrometastic disease. J Natl Cancer Inst 91: 1113-1124, 1999.
2. Hellman S: Stopping metastases at their source. N Engl J Med 337: 996-997, 1997.

3. Sidransky D: Nucleic acid-based methods for the detection of cancer. Science 278: 1054-1059, 1997.

4. Solakoglu O, Maierhofer C, Lahr G, et al: Heterogeneous proliferative potential of occult metastatic cells in bone marrow of patients with solid epithelial tumors. Proc Natl Acad Sci USA 99: 2246-2251, 2002.

5. Klein CA, Blankenstein TJ, Schmidt-Kittler O, Petronio M, Polzer B, Stoecklein NH and Riethmuller G: Genetic heterogeneity of single disseminated tumor cells in minimal residual cancer. Lancet 360: 683-689, 2002.

6. Schmidt-Kittler O, Ragg T, Daskalakis A, et al: From latent disseminated cells to overt metastasis: genetic analysis of systemic breast cancer progression. Proc Natl Acad Sci USA 100: 7737-7742, 2003.

7. Slamon DJ, Clark GM, Wong SG, Levin WJ, Ullrich A and McGurie WL: Human breast cancer: correlation of relapse and survival with amplification of the HER-2/neu oncogene. Science 235: 177-182, 1987

8. Slamon DJ, Godolphin W, Jones LA, et al: Studies of the HER-2/ neu proto-oncogene in human breast and ovarian cancer. Science 244: 707-712, 1989.

9. Hynes NE and Stern DF: The biology of erbB-2/neu/HER-2 and its role in cancer. Biochim Biophys Acta 1198: 165-184, 1994.

10. Revillion F, Bonneterre J and Peyrat JP: ERBB2 oncogene in human breast cancer and its clinical significance. Eur J Cancer 34: 791-808, 1998.

11. Yamauchi H, O'Neill A, Gelman R, Carney W, Tenney DY, Hosch S and Hayes DF: Prediction of response to antiestrogen therapy in advanced breast cancer patients by pretreatment circulating levels of extracellular domain of the HER-2/c-neu protein. J Clin Oncol 15: 2518-2525, 1997.

12. Berns EM, Foekens JA, van Staveren IL, van Putten WL, De Koning HY, Portengen $\mathrm{H}$ and Klijn JG: Oncogene amplification and prognosis in breast cancer: relationship with systemic treatment. Gene 159: 11-18, 1995.

13. Archer SG, Eliopoulos A, Spandidos D, et al: Expression of ras p21, p53 and c-erbB-2 in advanced breast cancer and response to first line hormonal therapy. Br J Cancer 72: 1259-1266, 1995.

14. Carlomagno C, Perrone F, Gallo C, et al: C-erb B2 overexpression decreases the benefit of adjuvant tamoxifen in earlystage breast cancer without axillary lymph node metastases. J Clin Oncol 14: 2702-2708, 1996.

15. Lipton A, Ali SM, Leitzel K, et al: Serum HER-2/neu and response to the aromatase inhibitor letrozole versus tamoxifen. $\mathrm{J}$ Clin Oncol 21: 1967-1972, 2003.

16. Lim HY, Joo HJ, Choi JH, et al: Increased expression of cyclooxygenase-2 protein in human gastric carcinoma. Clin Cancer Res 6: 519-525, 2000.

17. Wolff H, Saukkonen K, Anttila S, Karjalainen A, Vainio H and Ristimaki A: Expression of cyclooxygenase-2 in human lung carcinoma. Cancer Res 58: 4997-5001, 1998.

18. Mohammed SI, Knapp DW, Bostwick DG, et al: Expression of cyclooxygenase-2 (COX-2) in human invasive transitional cell carcinoma (TCC) of the urinary bladder. Cancer Res 59: 5647-5650, 1999.

19. Chan G, Boyle JO, Yang EK, et al: Cyclooxygenase-2 expression is up-regulated in squamous cell carcinoma of the head and neck. Cancer Res 59: 991-994, 1999.

20. Hwang D, Scollard D, Byrne J and Levine E: Expression of cyclooxygenase- 1 and cyclooxygenase- 2 in human breast cancer. J Natl Cancer Inst 90: 455-460, 1998.

21. Costa C, Soares R, Reis-Filho JS, Leitao D, Amendoeira I and Schmitt FC: Cyclo-oxygenase 2 expression is associated with angiogenesis and lymph node metastasis in human breast cancer. J Clin Pathol 55: 429-434, 2002.

22. Relf M, Le Jeune S, Scott PA, et al: Expression of the angiogenic factors vascular endothelial cell growth factor, acidic and basic fibroblast growth factor, tumor growth factor b-1, plateletderived endothelial growth factor, placenta growth factor and pleiotrophin in human primary breast cancer and its relation to angiogenesis. Cancer Res 57: 963-969, 1997.

23. Eppenberger U, Kueng W, Schlaeppi JM, et al: Markers of tumor angiogenesis and proteolysis independently define highand low-risk subsets of node-negative breast cancer patients. J Clin Oncol 16: 3129-3136, 1998.

24. Beck L and D'Amore PA: Vascular development: cellular and molecular regulation. FASEB J 11: 365-373, 1997. 
25. Shweiki D, Itin A, Soffer D and Keshet E: Vascular endothelial growth factor induced by hypoxia may mediate hypoxia-initiated angiogenesis. Nature 359: 843-845, 1992.

26. Fredriksson L, Li H and Eriksson U: The PDGF family: four gene products form five dimeric isoforms. Cytokine Growth Factor Rev Aug 15: 197-204, 2004.

27. Coltrera MD, Wang J, Porter PL and Gown AM: Expression of platelet-derived growth factor B-chain and the platelet-derived growth factor receptor beta subunit in human breast tissue and breast carcinoma. Cancer Res 15: 2703-2708, 1995.

28. Martell M, Gomez J, Esteban JI, et al: High-throughput realtime reverse transcription-PCR quantitation of hepatitis $\mathrm{C}$ virus RNA. J Clin Microbiol 37: 327-332, 1999.

29. Bieche I, Olivi M, Champeme MH, Vidaud D, Lidereau R and Vidaud M: Novel approach to quantitative polymerase chain reaction using real-time detection: application to the detection of gene amplification in breast cancer. Int J Cancer 78: 661-666, 1998.

30. Hu XC, Wang Y, Shi DR, Loo WTY and Chow LWC: Immunomagnetic tumor cell enrichment is promising in detecting circulating breast cancer cells. Oncology 64: 160-165, 2003.

31. Kenneth JL and Thomas DS: Analysis of relative gene expression data using real-time quantitative PCR and the $2^{-\Delta \Delta C t}$ method. Method 25: 402-408, 2001.

32. Redding WH, Coombes RC, Monaghan P, et al: Detection of micrometastases in patients with primary breast cancer. Lancet ii: $1271-1274,1983$.

33. Harbeck N, Untch M, Pache L and Eiermann W: Tumour cell detection in the bone marrow of breast cancer patients at primary therapy: results of a 3-year median follow-up. Br J Cancer 69: 566-571, 1994.

34. Mansi JL, Gogas H, Bliss JM, Gazet JC, Berger U and Coombes RC: Outcome of primary-breast-cancer patients with micrometastases: a long-term follow-up study. Lancet 354: 197-202, 1999.

35. Braun S, Pantel K, Muller P, et al: Cytokeratin-positive cells in the bone marrow and survival of patients with stage I, II or III breast cancer. N Engl J Med 342: 525-533, 2000.

36. Solomayer EF, Diel IJ, Salanti G, Hahn M, Gollan C, Schutz F and Bastert G: Time independence of the prognostic impact of tumor cell detection in the bone marrow of primary breast cancer patients. Clin Cancer Res 7: 4102-4108, 2001.

37. Gebauer G, Fehm T, Merkle E, Beck EP, Lang N and Jager W: Epithelial cells in bone marrow of breast cancer patients at time of primary surgery: clinical outcome during long-term follow-up. J Clin Oncol 19: 3669-3674, 2001.

38. Gerber B, Krause A, Muller H, et al: Simultaneous immunohistochemical detection of tumor cells in lymph nodes and bone marrow aspirates in breast cancer and its correlation with other prognostic factors. J Clin Oncol 19: 960-971, 2001.

39. Wiedswang G, Borgen E, Karesen R, et al: Detection of isolated tumor cells in bone marrow is an independent prognostic factor in breast cancer. J Clin Oncol 21: 3469-3478, 2003.

40. Naume B, Borgen E, Nesland JM, et al: Increased sensitivity for detection of micrometastases in bone marrow/peripheralblood stem-cell products from breast-cancer patients by negative immunomagnetic separation. Int J Cancer 78: 556-560, 1998.

41. Krag DN, Ashikaga T, Moss TJ, et al: Breast cancer cells in the blood: A pilot study. Breast J 5: 354-358, 1999.

42. Beitsch PD and Clifford E: Detection of carcinoma cells in the blood of breast cancer patients. Am J Surg 180: 446-448, 2000

43. Kraeft SK, Sutherland R, Gravelin L, et al: Detection and analysis of cancer cells in blood and bone marrow using a rare event imaging system. Clin Cancer Res 6: 434-442, 2000.

44. Kruger W, Datta C, Badbaran A, et al: Immunomagnetic tumor cell selection-implications for the detection of disseminated cancer cells. Transfusion 40: 1489-1493, 2000.

45. Kim SJ, Ikeda N, Shiba E, Takamura Y and Noguchi S: Detection of breast cancer micrometastases in peripheral blood using immunomagnetic separation and immunocytochemistry. Breast Cancer 8: 63-69, 2001.

46. Weihrauch MR, Skibowski E, Draube A, Geller A, Tesch H, Diehl V and Bohlen H: Immunomagnetic enrichment and detection of isolated tumor cells in bone marrow of patients with epithelial malignancies. Clin Exp Metastasis 19: 617-621, 2002.
47. Witzig TE, Bossy B, Kimlinger T, et al: Detection of circulating cytokeratin-positive cells in the blood of breast cancer patients using immunomagnetic enrichment and digital microscopy. Clin Cancer Res 8: 1085-1091, 2002.

48. Turner RR, Ollila DW, Krasne DL and Giuliano AE: Histopathologic validation of the sentinel lymph node hypothesis for breast carcinoma. Ann Surg 226: 271-278, 1997.

49. Turner RR, Ollila DW, Stern S and Giuliano AE: Optimal histopathologic examination of the sentinel lymph node for breast carcinoma staging. Am J Surg Pathol 23: 263-267, 1999.

50. Czerniecki BJ, Scheff AM, Callans LS, et al: Immunohistochemistry with pancytokeratins improves the sensitivity of sentinel lymph node biopsy in patients with breast carcinoma. Cancer 85: 1098-1103, 1999.

51. Schreiber RH, Pendas S, Ku NN, et al: Microstaging of breast cancer patients using cytokeratin staining of the sentinel lymph node. Ann Surg Oncol 6: 95-101, 1999.

52. Liu LH, Siziopikou KP, Gabram S and McClatchey KD: Evaluation of axillary sentinel lymph node biopsy by immunohistochemistry and multilevel sectioning in patients with breast carcinoma. Arch Pathol Lab Med 124: 1670-1673, 2000.

53. Canalis E and Rydziel S: Platelet-derived growth factor and the skeleton. In: Principles of Bone Biology. Bilezikian JB, Raisz LG and Rodan GA (eds). San Diego, Academic Press, pp619-626, 1996.

54. Yi B, Williams PJ, Niewolna M, Wang Y and Yoneda T: Tumorderived platelet-derived growth factor-BB plays a critical role in osteosclerotic bone metastasis in an animal model of human breast cancer. Cancer Res 62: 917-923, 2002.

55. Ariad S, Seymour L and Bezwoda WR: Platelet-derived growth factor in plasma of breast cancer patients: correlation with stage and rate of progression. Breast Cancer Res Treat 20: 11-17, 1991.

56. Seymour L, Dajee D and Berzwoda WR: Tissue platelet derived growth factor (PDGF) predicts for shortened survival and treatment failure in advanced breast cancer. Breast Cancer Res Treat 26: 247-252, 1993.

57. Seymour L and Berzwoda WR: Positive immunostaining for platelet-derived growth factor is an adverse prognostic factor in patients with advanced breast cancer. Breast Cancer Res Treat 32: 229-233, 1994.

58. Braun S, Schlimok G, Heumos I, Schaller G, Riethdorf L, Riethmuller G and Pantel K: ErbB2 overexpression on occult metastatic cells in bone marrow predicts poor clinical outcome of stage I-III breast cancer patients. Cancer Res 61: 1890-1895, 2001.

59. Ferrara $\mathrm{N}$ and Davis-Smyth T: The biology of vascular endothelial growth factor. Endocr Rev 18: 4-25, 1997.

60. Toi M, Inada K, Suzuki H and Tominaga T: Tumor angiogenesis in breast cancer: its importance as a prognostic indicator and the association with vascular endothelial growth factor expression. Breast Cancer Res Treat 36: 193-204, 1995.

61. Gasparini G, Toi M, Gion M, et al: Prognostic significance of vascular endothelial growth factor protein in node-negative breast carcinoma. J Natl Cancer Inst 89: 139-147, 1997.

62. Gasparini G, Toi M, Miceli R, et al: Clinical relevance of vascular endothelial growth factor and thymidine phosphorylase in patients with node-positive breast cancer treated with either adjuvant chemotherapy or hormone therapy. Cancer J Sci Am 5: 101-111, 1999.

63. Linderholm B, Tavelin B, Grankvist K and Henriksson R: Vascular endothelial growth factor is of high prognostic value in nodenegative breast carcinoma. J Clin Oncol 16: 3121-3128, 1998.

64. Linderholm B, Grankvist K, Wilking N, Johansson M, Tavelin B and Henriksson R: Correlation of vascular endothelial growth factor content with recurrences, survival and first relapse site in primary node-positive breast carcinoma after adjuvant treatment. J Clin Oncol 18: 1423-1431, 2000.

65. Kurebayashi J, Otsuki T, Kunisue H, Mikami Y, Tanaka K, Yamamoto $\mathrm{S}$ and Sonoo H: Expression of vascular endothelial growth factor (VEGF) family members in breast cancer. Jpn J Cancer Res 90: 977-981, 1999.

66. Schrey MP and Patel K: Prostaglandin E2 production and metabolism in human breast cancer cells and breast fibroblasts. Regulation by inflammatory mediators. Br J Cancer 72: 1412-1419, 1995. 